\title{
Naphthaleneacetic Acid Reduces Leader Growth of Fraser Fir Christmas Trees
}

\author{
M. Elizabeth Rutledge ${ }^{1}$, John Frampton ${ }^{2}$, and Gary Blank ${ }^{3}$ \\ Department of Forestry and Environmental Resources, North Carolina State \\ University, Raleigh, NC 27695-8008
}

L. Eric Hinesley ${ }^{2,4}$

Department of Horticultural Science, North Carolina State University, Box 7609, Raleigh, NC 27695-7609

Additional index words. Abies fraseri, consumer preference, shearing, Easy Roller, Sprühsystem

\begin{abstract}
Two methods of application, the Danish Easy Roller and the German Sprühsystem, were tested to evaluate the effectiveness of naphthaleneacetic acid (NAA) at reducing leader growth (tips of primary axes) of fraser fir [Abies fraseri (Pursh) Poir.] Christmas trees. A commercial product, Sucker-Stopper RTU (1.15\% ethyl 1-NAA), was applied to leaders at concentrations of 0 to $500 \mathrm{~mL} \cdot \mathrm{L}^{-1}$ when leaders were 8 to $15 \mathrm{~cm}$ long. As the concentration increased, leader elongation decreased. The Easy Roller reduced leader growth the most, but leader mortality was unacceptable at concentrations $20 \mathrm{~mL} \cdot \mathrm{L}^{-1}$ or greater. Although less effective than the Easy Roller, the Sprühsystem caused negligible mortality of leaders. Applying $40 \mathrm{~mL} \cdot \mathrm{L}^{-1}$ with the Easy Roller yielded $\approx 50 \%$ of leaders with target lengths of 20 to $36 \mathrm{~cm}$ with little mortality. The Sprühsystem gave similar results at $250 \mathrm{~mL} \cdot \mathrm{L}^{-1}$. NAA might be useful for producing dense trees with minimal shearing or for producing more natural, open trees during shorter rotations.
\end{abstract}

Fraser fir (Abies fraseri) is an important Christmas tree species both locally and nationally [North Carolina Christmas Tree Association, 2004; North Carolina Department of Agriculture and Consumer Services (NCDA\&CS), 2005]. It is sheared once annually beginning at a height of 1 to $1.3 \mathrm{~m}$. Shearing in July and August is optimal (Hinesley and Derby, 2004a, 2004b) to produce dense trees for American consumers. Traditional shearing removes the apical bud cluster from the leader (distal end of the primary axis) and most lateral branches. Leaders are usually shortened to 20 to 50 $\mathrm{cm}$, often half the original length, depending

\footnotetext{
Received for publication 10 July 2007. Accepted for publication 29 Oct. 2007.

This research was funded by the North Carolina Agricultural Research Service (NCARS), Raleigh, NC, through the Christmas Tree Genetics Program. We thank Avery County Extension Director Jerry Moody and Avery County IPM Technician Doug Hundley for guidance and support. We also thank Avery County Christmas tree growers Waightstill Avery, Robert Reece, and Jack Wiseman for allowing us to use their Christmas trees.

Use of trade names in this publication does not imply endorsement by the NCARS of products named nor criticism of similar ones not mentioned. This paper is from M.E. Rutledge's MS thesis.

${ }^{1}$ Graduate student

${ }^{2}$ Professor.

${ }^{3}$ Associate Professor.

${ }^{4}$ To whom reprint requests should be addressed; e-mail eric_hinesley@ncsu.edu.
}

produced hormone that causes inactivation of auxins, leaf abscission, and growth inhibition (Kefeli and Kalevitch, 2003). At high levels, NAA can reduce growth and cause injury or death to plants (Boswell et al., 1976; Domir and Wuertz, 1982; Hare, 1982; Kramer and Kozlowski, 1979; Wilson, 1983). Therefore, objectives of this research were to 1) determine the effect of SS-RTU on leader growth of fraser fir; and 2) compare two methods of application.

\section{Materials and Methods}

Two methods of application were used. The Easy Roller (Easy Roller; Lars B. Madsen, Langmosevej 6, 8620 Kjellerup, Denmark) has two rollers mounted parallel on the end of two metal extensions (Fig. 1A). The roller apparatus connects to a push-pump container by plastic tubing. The two rollers are placed on either side of the base of the leader and gently rolled upward as a chemical is pumped through the rollers and dispensed onto the leader (Fig. 1B). The chemical is applied until foliage is wet, which takes only a few seconds. The Sprühsystem (Michael Scherer, Donauwörth, Germany), which uses a backpack sprayer, has two nozzles that are contained in a cage-like box along with three small rollers that are used for application (Fig. 1C). The cage, acting as a shield, slides from the base of the leader to the terminal while a fine chemical spray is dispensed by a trigger (applied according to the manufacturer's instructions) on the handle of the applicator (Fig. 1D). At 0.2 to $0.4 \mathrm{MPa}$, the Sprühsystem dispenses $\approx 24 \mathrm{~mL}$ of solution in $30 \mathrm{~s}$ and requires $\approx 3 \mathrm{~s}$ to cover a $45-\mathrm{cm}$ leader.

The research was conducted in the mountains of western North Carolina during Spring and Summer 2006. The three test sites - typical of fraser fir Christmas tree plantations - were 920 to $1200 \mathrm{~m}$ above sea level. A total of 1500 sheared trees was used (height, 1.2 to $1.5 \mathrm{~m}$ ). Most trees had been in the field for 5 to 6 years and were likely 5 years from seed when planted. Trees shorter than $1.2 \mathrm{~m}$ or taller than $1.5 \mathrm{~m}$ as well as trees with noticeable disease or insect damage were not used.

The completely randomized block design consisted of three sites with 50 blocks per site and 10 trees per block. Each tree was randomly assigned one of the 10 treatment combinations.

Before the experiment, total tree height (growth through 2005) and the sheared height up to the previous year's whorl (growth through 2004) were recorded. Leader length for the 2005 growing season was calculated by difference. The length and the width of each tree's apical bud were measured using digital calipers. The two bud widths were averaged and multiplied by the apical bud length to derive a bud volume index. These measurements were taken to determine if there were significant relationships between the pretreatment measurements and final leader length. 

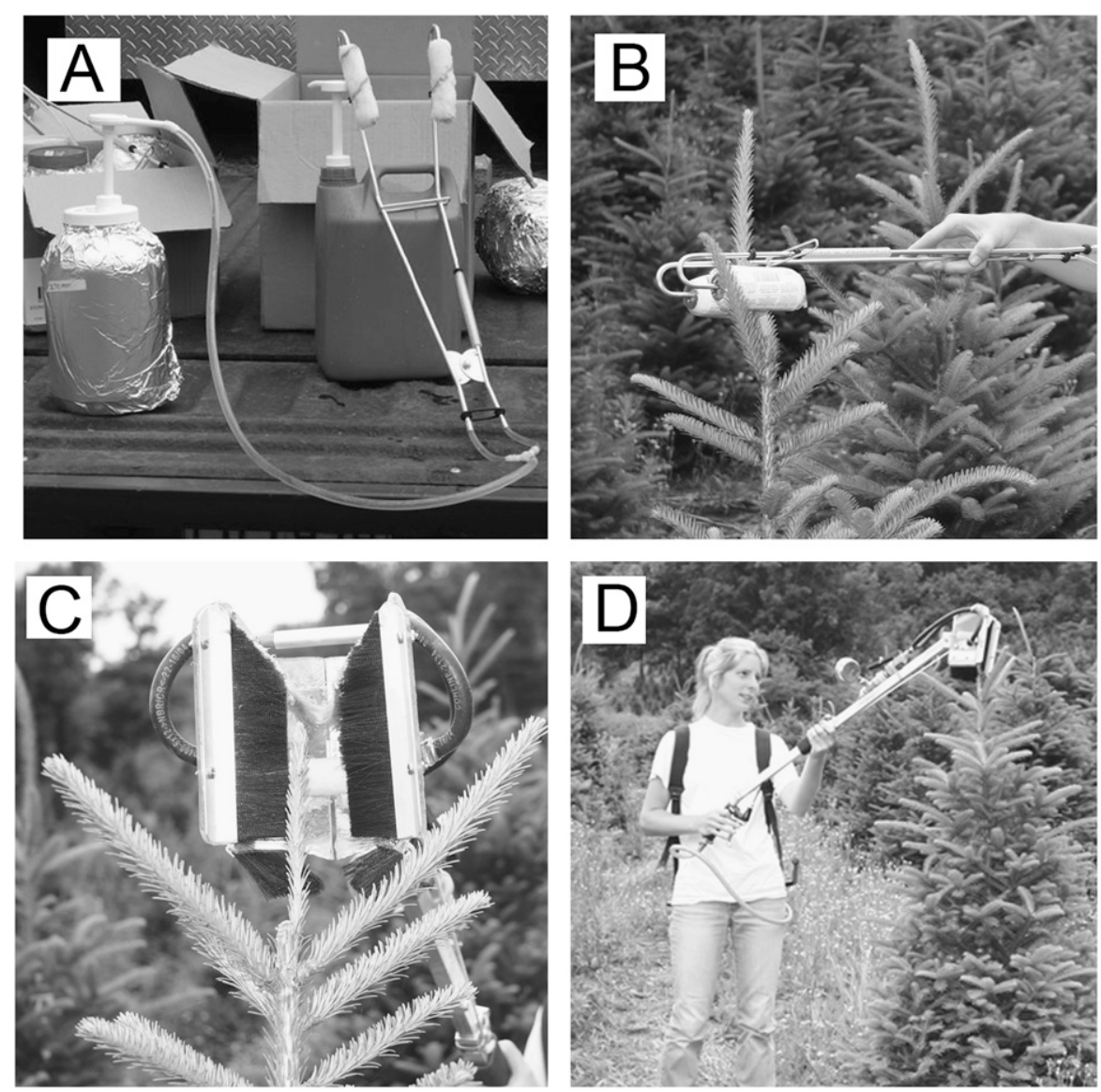

Fig. 1. Applicator components and application of Sucker-Stopper. (A) Easy Roller, (B) Easy Roller application, (C) Sprühsystem, and (D) Sprühsystem application.

Seven treatments were applied with the Easy Roller: control (leaders treated with water), $40,80,120,160,250$, or $500 \mathrm{~mL} \cdot \mathrm{L}^{-1}$. Concentrations of 40,120 , and $250 \mathrm{~mL} \cdot \mathrm{L}^{-1}$ were applied with the Sprühsystem. Treatments were applied only during warm, dry periods of the day to allow for adequate drying. Solutions were mixed with distilled water and also contained $10 \mathrm{~mL} \cdot \mathrm{L}^{-1}$ of WA100 Plus (Ag Spray, Inc., Salem, OR), a surfactant. Trees were checked regularly, and treatments were applied as the new leaders reached a length of 8 to $15 \mathrm{~cm}$.

In Fall 2006, the number of lateral buds was counted on each leader. The length of the lowest lateral branch on the south side of the 2005 leader was measured to determine if SSRTU affected lateral branch growth. Finally, leaders were rated for foliage injury (percent) using a scale of 1 to 5: $1=$ alive and healthy and $5=$ dead. Categories 2, 3, and 4 represented foliage injury levels of $1 \%$ to $33 \%$, $34 \%$ to $67 \%$, and $68 \%$ to $99 \%$, respectively.

For Site 2, beginning 26 June 2006, average leader length was recorded for Weeks 1, 2, 3, 4, 5, 6, 7, and 9; measurements on the other two sites were for Week 9 only. Data were analyzed using GLM and REG procedures (SAS Institute, Inc., Cary, NC). Analysis of variance was conducted to test for differences among main effects and interactions for site, concentration, and method of application. Correlation coefficients were calculated using CORR procedures (SAS Institute, Inc.) to determine the strength of the relationships between the pretreatment measurements and final leader length.

Leader length was evaluated relative to two shearing regimes: traditional and accelerated. These regimes refer to the leader length, which is normally set during shearing. Traditional leaders are 20 to $36 \mathrm{~cm}$, whereas the target range for accelerated leaders is 30 to $46 \mathrm{~cm}$. For each shearing regime, leaders were grouped into three categories: short, within the target range, or long.

\section{Results}

For both application methods, as the concentration of NAA increased, average leader elongation decreased (Figs. 2, 3, and 4A). This was true for both applicators and all concentrations of SS-RTU except for the 120 $\mathrm{mL} \cdot \mathrm{L}^{-1}$ and $160 \mathrm{~mL} \cdot \mathrm{L}^{-1}$ response curves for the Easy Roller, which were inverted (Fig. 2). We have no explanation for this occurrence. The response to SS- RTU for leader length and bud count significantly differed between sites, concentrations, and methods of application (Table 1). With regard to leader length, there were also significant interactions for applicator $\times$ concentration and site $\times$ applicator. Across all sites and applicators, there was a significant positive correlation between final leader length in 2006 and tree height in

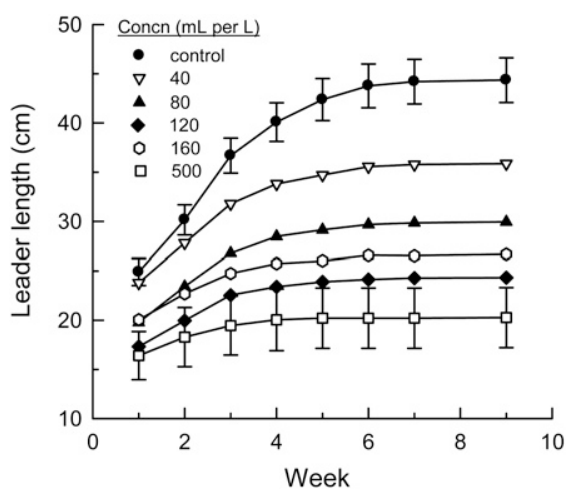

Fig. 2. Leader length of fraser fir Christmas trees on Site 2 as affected by concentration of Sucker-Stopper RTU. Applicator was the Easy Roller. Curves for 120 and $250 \mathrm{~mL} \cdot \mathrm{L}^{-1}$ were similar. Data points: $\mathrm{n}=50$; bars $=\mathrm{SE}$ of the mean.

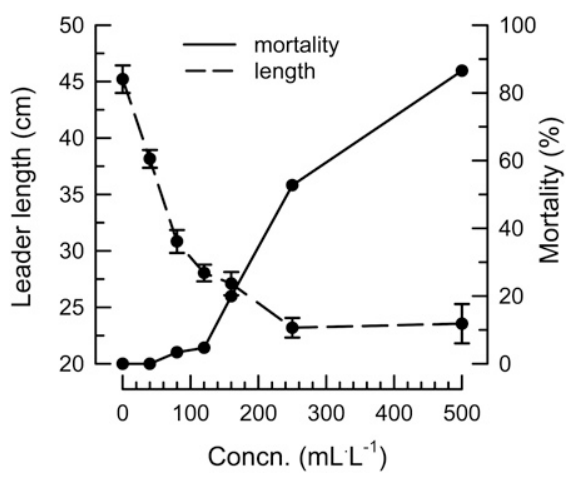

Fig. 3. Leader growth and mortality (averaged overall sites) for fraser fir Christmas trees treated with various concentrations of SuckerStopper RTU using the Easy Roller. Data points: $\mathrm{n}=150$; bars $=$ SE of the mean.

$2005(r=0.24, P<0.01)$ as well as final leader length in 2006 and bud volume in 2005 $(r=0.49, P<0.01)$. With the Easy Roller (all sites), there was a significant positive relationship between final leader length in 2006 and tree height in $2005(r=0.21, P<0.01)$ as well as final leader length in 2006 and bud volume in $2005(r=0.44, P<0.01)$. For treatments that were applied with the Sprühsystem, similar correlations occurred between final leader length in 2006 and tree height in $2005(r=0.29, P<0.01)$ as well as final leader length in 2006 and bud volume in $2005(r=0.52, P<0.01)$.

Of the two methods of application, the Easy Roller reduced leader elongation most effectively (Fig. 4A). A concentration of 40 $\mathrm{mL} \cdot \mathrm{L}^{-1}$ reduced leader length by $16 \%$ with negligible mortality (Fig. 3). Increasing the concentration to $80 \mathrm{~mL} \cdot \mathrm{L}^{-1}$ reduced leader length by $32 \%$ with leader mortality of $3 \%$. Mortality increased from 5\% for the 120 $\mathrm{mL} \cdot \mathrm{L}^{-1}$ treatment to $57 \%$ for $250 \mathrm{~mL} \cdot \mathrm{L}^{-1}$ and $86 \%$ for $500 \mathrm{~mL} \cdot \mathrm{L}^{-1}$ (Fig. 3). The Sprühsystem was less effective at reducing leader elongation, but leader mortality never exceeded $4 \%$ even at $250 \mathrm{~mL} \cdot \mathrm{L}^{-1}$ (Fig. 4B). The biggest difference was at $250 \mathrm{~mL} \cdot \mathrm{L}^{-1}$ in which the Easy Roller reduced leader length 

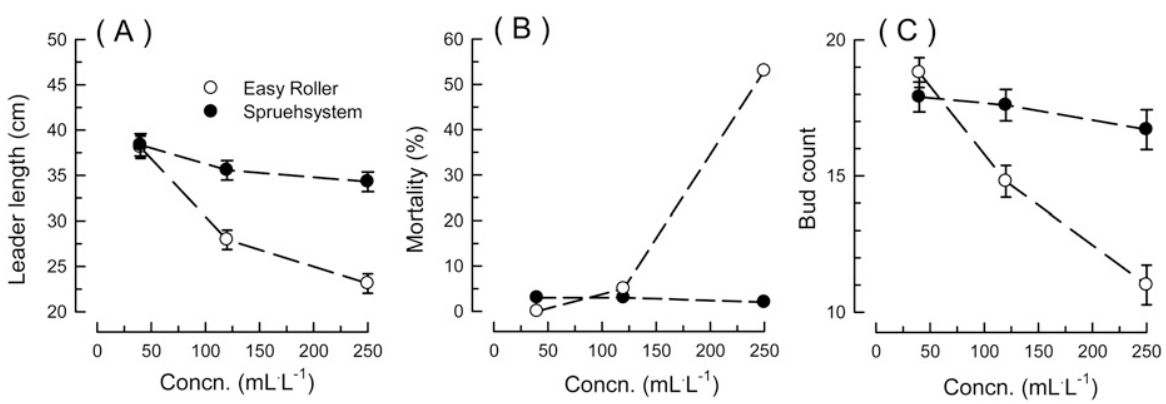

Fig. 4. Length (A), mortality (B), and bud count (C) of leaders of fraser fir Christmas trees as affected by concentration of SS-RTU and method of application. Data points: $n=150$; bars $=$ SE of the mean.

Table 1. Analysis of variance for final leader length, bud count, and lateral branch length of fraser fir Christmas trees treated with Sucker-Stopper RTU.

\begin{tabular}{lcccc}
\hline Source of variation & df & Leader length & Bud count & Lateral branch growth \\
\hline- Site (S) & 2 & NS & $*$ & $*$ \\
Concn. (C) & 6 & $* *$ & $*$ & NS \\
S $\times$ C & 12 & NS & NS & NS \\
\hline S & 2 & $* *$ & NS & $*$ \\
C & 2 & $*$ & NS & NS \\
S $\times$ C & 4 & NS & NS & NS \\
- S & 2 & $* *$ & $* *$ & $*$ \\
C & 2 & $* *$ & $* *$ & NS \\
Applicator $=$ A & 1 & $* *$ & $* *$ & NS \\
S $\times$ C & 2 & NS & NS & NS \\
S $\times$ A & 4 & $*$ & NS & NS \\
C $\times$ A & 2 & $* *$ & NS & NS \\
S $\times$ C $\times$ A & 4 & NS & & \\
\hline
\end{tabular}

zThere were three sites, 50 blocks per site, and 10 trees per block.

Ns, *, **Nonsignificant or significant at $P \leq 0.05$.

by $50 \%$ compared with $24 \%$ for the Sprühsystem (Fig. 4A).

There were significant differences in bud count for sites, concentrations, and methods of application for both applicators (Table 1). In addition, there was a significant interaction for concentration $\times$ applicator for bud count (Fig. 4C). Lateral branch growth differed only among sites and was unaffected by concentration or method of application (Table 1). There was no clear relationship between lateral branch growth and leader length.

When final leader lengths were categorized (short, target, or long), the percentage of trees in each category varied by concentration of SS-RTU and by shearing regime (traditional versus accelerated). Short leaders are more desirable than excessively long leaders. Lower concentrations yielded a higher percentage of "long" leaders. In the control treatment (no NAA), $73 \%$ of the leaders were longer than $36 \mathrm{~cm}$ (upper limit for "traditional" shearing regime) compared with $2 \%$ of leaders treated with $500 \mathrm{~mL} \cdot \mathrm{L}^{-1}$ from the Easy Roller (Fig. 5A). When applied with the Easy Roller, concentrations 120 $\mathrm{mL} \cdot \mathrm{L}^{-1}$ or greater yielded the most leaders 20 to $36 \mathrm{~cm}$ long, the target length for "traditional" shearing (Fig. 5A), but leader mortality was $20 \%$ for the $160 \mathrm{~mL} \cdot \mathrm{L}^{-1}$ concentration and increased sharply at higher concentrations (Fig. 3). Using the Easy Roller, the highest percentage of leaders 30 to $46 \mathrm{~cm}$ in length (target range for "accelerated" shearing) was $\approx 50 \%$ with a concentration of 40 $\mathrm{mL} \cdot \mathrm{L}^{-1}$ of SS-RTU (Fig. 5B). When applied with the Sprühsystem, $250 \mathrm{~mL} \cdot \mathrm{L}^{-1}$ yielded $55 \%$ of leaders in the target range for the "traditional" shearing regime compared with $45 \%$ for the $120 \mathrm{~mL} \cdot \mathrm{L}^{-1}$ concentration in the "accelerated" shearing regime (Fig. 5C-D).

\section{Discussion}

The Easy Roller and the Sprühsystem both reduced leader growth of fraser fir Christmas trees (Table 1; Figs. 2, 3, and 4A). In a similar experiment in the Pacific Northwest, NAA in combination with the Top-Stop Nipper (a tool used for making cuts into the bark of the leader; Top-Stop; Lars Geil, Ry, Denmark) reduced leader length in Noble fir (Abies procera Rehd.) and Nordmann fir (Abies nordmanniana Spach) by $25 \%$ to $50 \%$, respectively, although the response varied by species, treatment, and individual tree (Fletcher et al., 2005). In another experiment in the United Kingdom, Tipoff XT (Universal Crop Protection Ltd., Cookham, Maidenhead, Berkshire, UK), a growth regulator containing $0.29 \%$ NAA, was applied to fraser fir with the Easy Roller at 0 to $150 \mathrm{~mL} \cdot \mathrm{L}^{-1}$, and leader length decreased with increasing concentration. Only $20 \%$ of the nonsheared control trees had leader lengths in the target range compared with $44 \%$ with $150 \mathrm{~mL} \cdot \mathrm{L}^{-1}$ (L. Madsen, personal communication).

With the Easy Roller, leader damage and mortality increased with increasing concentration of SS-RTU (Fig. 3). Mortality was unacceptable (20\% to $86 \%$ ) at concentrations 160 $\mathrm{mL} \cdot \mathrm{L}^{-1}$ or greater, whereas the Sprühsystem caused negligible mortality even at the highest concentration of $250 \mathrm{~mL} \cdot \mathrm{L}^{-1}$. We do not have an explanation for this difference. The Sprühsystem sprays a constant concentration of solution onto the leaders. The Easy Roller applies solution directly to the leader, and the application rate might vary depending on the texture and surface features of the foliage, e.g., smooth, rough, short nap, course nap. Also, the concentration of SS-RTU as well as the surfactant might increase on the roller surfaces as water evaporates, similar to latex paint drying on the surface of a brush or roller. The output of the Easy Roller was not determined when treatments were applied. Even if the output were known, additional research might be required to determine the reason for the high leader mortality at concentrations 160 $\mathrm{mL} \cdot \mathrm{L}^{-1}$ or greater.

In the separate analyses for the Easy Roller and Sprühsystem, there were significant main effects for site and concentration but no significant interactions (Table 1 ). We do not know the basis for the site variation (soil, temperature, rainfall, other), but significant variation in tree growth is common among sites. In the combined analysis, the significant interaction for applicator $\times$ concentration $(\mathrm{A} \times \mathrm{C})$ indicates there was a clear response to changing concentrations of NAA, but it varied from site to site depending on the method of application. Thus, results are presented and interpreted separately for each method of application.

In fraser fir, a close relative of balsam fir (Abies balsamea L.), terminal leader formation is a 2-year process beginning with the formation of bud primordia (Powell, 1982). Optimum environmental conditions during that phase can yield more shoot growth the next growing season (Kozlowski, 1962). In determinant species, bud size is a good predictor of subsequent shoot length (Kozlowski et al., 1973; Little, 1970). Application of a plant growth regulator such as NAA may complicate the relationship between bud size and final leader length by altering hormonal balances.

Compared with the Sprühsystem, the Easy Roller would be more useful to growers who manage their trees for leaders longer than the traditional 20 to $36 \mathrm{~cm}$, i.e., accelerated shearing regime. When SS-RTU was applied at $40 \mathrm{~mL} \cdot \mathrm{L}^{-1}, \approx 50 \%$ of the leaders were within the accelerated target range with no mortality. Furthermore, for both methods of application, as the concentration of SSRTU increased, more trees fell into the short range than the long range - a preferred outcome. The Sprühsystem reduced leader growth with little mortality at concentrations $250 \mathrm{~mL} \cdot \mathrm{L}^{-1}$ or less, whereas the Easy Roller suppressed leader growth more effectively but with unacceptable mortality at concentrations $80 \mathrm{~mL} \cdot \mathrm{L}^{-1}$ or greater. Mechanical shearing 

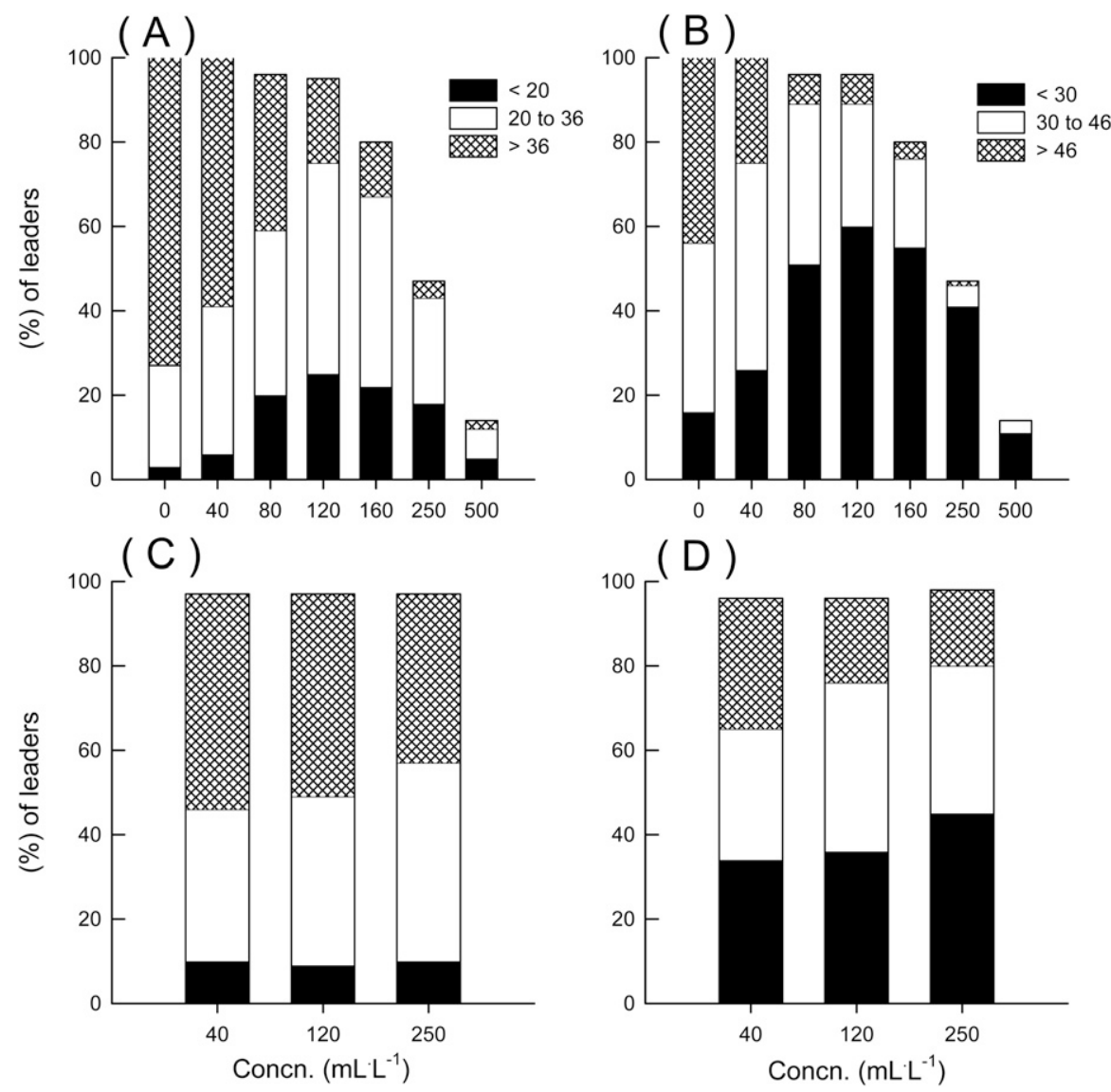

Fig. 5. Percentages of trees that measured within each range for final leader length; short, target, and long. Bars only include living leaders. The traditional target range for leader length is 20 to $36 \mathrm{~cm}$; the accelerated is 30 to $46 \mathrm{~cm}$. (A) Traditional regime for the Easy Roller, (B) accelerated regime for the Easy Roller, (C) traditional regime for the Sprühsystem, and (D) accelerated regime for the Sprühsystem.

puts virtually all leaders within the preferred target range compared with $50 \%$ for chemical treatment with SS-RTU. Thus, mechanically sheared trees would be more uniform in height with less variation among individual trees. A third alternative might be a hybrid regime in which trees with excessive leader length after treatment with SS-RTU could be conventionally sheared, whereas trees with leaders in the target range could remain untouched to preserve the natural appearance.

Nonsheared trees produce more biomass (stems and foliage) than sheared trees (Hinesley and Derby, 2004b); therefore, reducing branch growth and elongation while leaving a higher number of buds intact will produce a dense, more natural whorled tree. It appears that chemical applications alone are not sufficient; combining the chemical treatment with other methods (conventional shearing and/or TopStop Nipper) would increase the percentage of leaders in the target range, but at increased cost compared with a single conventional shearing each year.

The cost of SS-RTU is $\approx \$ 32.00$ per bottle $(0.66 \mathrm{~L}=0.17 \mathrm{gal}=22 \mathrm{oz})$. For a concentration of $160 \mathrm{~mL} \cdot \mathrm{L}^{-1}$, at least 6000 leaders (length, 8 to $15 \mathrm{~cm}$ ) could be treated with one bottle of concentrate (less than 1 cent per tree for the chemical). The application time per tree is only 2 to $3 \mathrm{~s}$, so the additional labor associated with application would be small. The advantage of chemical treatments, compared with conventional shearing, is that perhaps $50 \%$ of the trees would have a natural appearance with more distinctive branch whorls. The usefulness of SSRTU would likely improve if applied to genetic selections that produce heavier bud set and less shoot elongation compared with average trees.

Consumer preferences might influence the use of SS-RTU in Christmas tree production. SS-RTU could be used to produce a more open "European-style" tree. Many consumers would pay the same price for a full or open tree, and some would pay more for an open tree (Helmsing, 2003). In general, women prefer a more open "European-style" tree (Helmsing, 2003), but preferences are influenced by culture and demographics (Dishneau, 2004). Ultimately, the marketplace will determine Christmas tree production practices, and these findings may influence the practicality of using growth regulating chemicals for leader growth reduction.

\section{Literature Cited}

Bandurksi, R.S. and H.M. Nonhebel. 1984. Auxins, p. 1-16. In: Wilkins, B. (ed.). Advanced plant physiology. Wiley, New York, NY.

Bir, R.E. and T.G. Ranney. 1992. Suppression of basal sprouts on Betula nigra. SNA Res. Conf. 37:236-237.

Boswell, S.B., B.O. Bergh, and R.H. Whitsell. 1976. Control of sprouts on topworked avocado stumps with NAA formulations. HortScience 11:113-114.

Chastagner, G.A. and D.M. Benson. 2000. The Christmas tree: Traditions, production, and diseases. Plant Health Progress, Plant Health Rev. DOI:10.1094/PHP-2000-1013-01-RV.

Dishneau, D. 2004. Grower suggests opening your mind to more open Christmas trees. 28 Mar. 2007. Associated Press, <http://wtop.com/index. php?nid=25\&pid=0\&sid=344346\&page $=1>$.

Domir, S.C. and D.E. Wuertz. 1982. Growth retardation of woody species by three growth regulators. Plant Growth Regulat. 1:107-111.

Fletcher, R., C. Landgren, and M. Bondi. 2005. Control of Abies leader growth in Oregon Christmas trees via chemical and mechanical manipulation, p. 14-15. 7th Intl. Christmas Tree Res. and Ext. Conf. Program and Abstr., 2-7 Oct. 2005, Tustin, MI. Michigan State Univ., East Lansing, MI.

Frampton, J. and C.R. McKinley. 1999. Christmas trees and greenery in Denmark: Production and tree improvement. Amer. Christmas Tree J. 43:4-11.

Hare, R.C. 1982. Effect of nine growth retardants applied to loblolly and slash pine. Can. J. For. Res. 12:112-114.

Hellgren, J.M. 2003. Ethylene and auxin in the control of wood formation. $\mathrm{PhD}$ thesis, Silvestria 268. Swedish Univ. of Agr. Sci., Umeå, Sweden.

Helmsing, P. 2003. The perfect Christmas tree. Amer. Christmas Tree J. 47:34-35.

Hinesley, L.E. and S.A. Derby. 2004a. Shearing date affects growth and quality of fraser fir Christmas trees. HortScience 39:1020-1024.

Hinesley, L.E. and S.A. Derby. 2004b. Growth of fraser fir Christmas trees in response to annual shearing. HortScience 39:1644-1646.

Hinesley, L.E., S.L. Warren, and L.K. Snelling. 1998. Effect of uniconazole on shoot growth and budset of containerized fraser fir. HortScience 33:82-84.

Kefeli, V.I. and M.V. Kalevitch. 2003. Natural growth inhibitors and phytohormones in plants and environment. Kluwer Academic Publishers, Dordrecht, The Netherlands.

Kozlowski, T.T. 1962. Tree growth. Ronald Press, New York, NY.

Kozlowski, T.T., J.H. Torrie, and P.E. Marshall. 1973. Predictability of shoot length from bud size in Pinus resinosa Ait. Can. J. For. Res. 3:34-38.

Kramer, P.J. and T.T. Kozlowski. 1979. Physiology of woody plants. Kluwer Academic Publishers, New York, NY.

Little, C.H.A. 1970. Apical dominance in long shoots of white pine (Pinus strobus). Can. J. Bot. 48:239-253.

North Carolina Christmas Tree Association. 2004. Tree facts. 18 Feb. 2007. <http://www.ncchristmastrees. com/facts.htm>.

North Carolina Department of Agriculture and Consumer Services. 2002. Evaluation of the competitive position of the fraser fir Christmas tree. Div. of Mktg., Div. of Agr. Stat.

North Carolina Department of Agriculture and Consumer Services. 2005. Choose and cut guide facts for fraser fir. 28 Oct. 2005. <http:// www.ncagr.com/markets/commodit/horticul/ xmastree/index.htm>.

Powell, G.R. 1982. Shoot and bud development in balsam fir: Implications for pruning of Christmas trees. For. Chron. 58:168-172.

Wilson, W.C. 1983. The use of exogenous plant growth regulating chemicals on citrus, p. 211. In: Nickell, L.G. (ed.). Plant growth regulating chemicals. Vol. 1. CRC Press, Inc., Boca Raton, FL. 